Note: This is a cover page, not part of the manuscript.

\title{
Ion Recognition Approach to Volume Reduction of Alkaline Tank Waste by Separation and Recycle of Sodium Hydroxide and Sodium Nitrate
}

\author{
Bruce A. Moyer, ${ }^{*}$ Peter V. Bonnesen, Gilbert M. Brown, Jeffrey C. Bryan, C. Kevin Chambliss, \\ Tamara J. Haverlock, and Tatiana G. Levitskaia \\ Chemical and Analytical Sciences Division, Oak Ridge National Laboratory, \\ P.O. Box 2008, Oak Ridge, TN 37830-6119
}

\author{
Alan P. Marchand* \\ Department of Chemistry, University of North Texas, \\ NT Station, P.O. Box 305070, Denton, TX 76203-5070
}

FY 2001 Annual Report to be submitted to the Environmental Management Science Program and to be posted on the internet.

\section{CAUTION}

The submitted manuscript has been authored by a contractor of the U. S. Government under contract No. DE-AC05-00OR22725. Accordingly, the U.S. Government retains a non-exclusive, royalty-free license to publish or reproduce the published form of this contribution, or allow others to do so, for the U.S. Government purposes.

This research was sponsored by the Environmental Management Science Program of the Offices of Science and Environmental Management, U. S. Department of Energy, under a) contract number DE-AC05-00OR22725 with Oak Ridge National Laboratory, managed and operated by UT-Battelle, LLC, and b) Grant number DE-FG07-98ER14936 with the University of North Texas. The participation of C.K.C. and T.G.L. was made possible by an appointment to the Oak Ridge National Laboratory Postgraduate Program administered by the Oak Ridge Associated Universities. 


\section{Project 65339 FY 2001 Annual Report}

Ion Recognition Approach to Volume Reduction of Alkaline Tank Waste by Separation and Recycle of Sodium Hydroxide and Sodium Nitrate

Aug. 3, 2001

Lead Principal Investigator: Bruce A. Moyer, Oak Ridge National Laboratory, Bldg. 4500S, MS 6119, P.O. Box 2008, Oak Ridge, TN 37831-6119. Phone: 865-574-6718. Fax: 865-574-4939. E-mail: moyerba@ornl.gov

Co-Investigator: Prof. Alan P. Marchand, Dept. of Chemistry, University of North Texas, NT Station, Box 305070, Denton, TX 76203. Phone: 940-369-7226. Fax: 940-369-7374. E-mail: marchand@unt.edu

Researcher: Peter V. Bonnesen, Oak Ridge National Laboratory, Bldg. 4500S, MS 6119, P.O. Box 2008, Oak Ridge, TN 37831-6119. Phone: 865-574-6715. Fax: 865-574-4939. E-mail: bonnesenpv@ornl.gov

Researcher: Gilbert M. Brown, Oak Ridge National Laboratory, Bldg. 4500S, MS 6119, P.O. Box 2008, Oak Ridge, TN 37831-6119. Phone: 865-572-2756. Fax: 865-574-4939. E-mail: browngm1@ornl.gov

Researcher: Jeffrey C. Bryan, Oak Ridge National Laboratory, Bldg. 4500S, MS 6119, P.O. Box 2008, Oak Ridge, TN 37831-6119. Phone: 865-574-5018. Fax: 865-574-4939. E-mail: bryanjc@ornl.gov

Researcher: Tamara J. Keever, Oak Ridge National Laboratory, Bldg. 4500S, MS 6119, P.O. Box 2008, Oak Ridge, TN 37831-6119. Phone: 865-574-6714. Fax: 865-574-4939. E-mail: keevertj@ornl.gov

Number of graduate students: 3 (UNT)

Number of postdocs: 9 ( 2 at ORNL and 7 at UNT) 


\section{Research Objective}

Disposal of high-level nuclear waste is horrendously expensive, in large part because the actual radioactive matter in the tanks has been diluted over 1000-fold by ordinary inorganic chemicals. Treatment processes themselves can exacerbate the problem by adding further volume to the waste. Waste retrieval and sludge washing, for example, will require copious amounts of sodium hydroxide. If the needed sodium hydroxide could be separated from the waste and recycled, however, the addition of fresh sodium hydroxide could be avoided, ultimately reducing the final waste volume and associated disposal costs.

The major objective of this research is to explore new liquid-liquid extraction approaches to the selective separation of sodium hydroxide from alkaline high-level wastes stored in underground tanks at the Hanford and Savannah River sites. Consideration is also given to separating potassium and abundant anions, including nitrate, nitrite, aluminate, and carbonate. Salts of these ions represent possible additional value for recycle, alternative disposal, or even use as commodity chemicals.

A comprehensive approach toward understanding the extractive chemistry of these salts is envisioned, involving systems of varying complexity, from use of simple solvents to new bifunctional host molecules for ion-pair recognition. These extractants will ideally require no adjustment of the waste composition and will release the extracted salt into water, thereby consuming no additional chemicals and producing no additional waste volume. The overall goal of this research is to provide a scientific foundation upon which the feasibility of new liquidliquid extraction chemistry applicable to the bulk reduction of the volume of tank waste can be evaluated.

\section{Research Progress and Implications}

This report summarizes work performed during the final 15 months of a three-year project. Experiments have focused on identifying candidate extraction systems possessing appreciable loading, effective stripping with water, and adequate selectivity for hydroxide. Of eight possible fundamental approaches to developing such extractants, three have proven most promising and have received focused attention. All three approaches employ a cation-exchange principle in which a very weakly acidic reagent exchanges a proton for sodium ion at elevated $\mathrm{pH}$ values characteristic of alkaline tank waste. Contact of the solvent phase with water then regenerates the neutral alcohol by hydrolysis, releasing sodium hydroxide into the water. Based on this principle, the first type of system entails use of alkylated phenols or fluorinated alcohols as cation exchangers for sodium. Since hydroxide ion is not actually extracted, this type of system has been designated "pseudo hydroxide extraction." When the cation exchangers are combined with macrocyclic sodium ion receptors, the second type of system, designated "synergized pseudo hydroxide extraction" is obtained. A third type of system employs ditopic macrocyclic sodium ion receptors containing ionizable groups for cation exchange of sodium.

As an example of "pseudo hydroxide extraction," the fluorinated alcohol $1 \mathrm{H}, 1 \mathrm{H}, 9 \mathrm{H}-$ hexadecafluorononanol (HDFN) in 1-octanol has sufficient acidity to be converted to its sodium salt when contacted with highly alkaline aqueous solutions. Using 1-octanol as a diluent, a series of fluorinated alcohols and selected lipophilic phenols were shown in the first two years of the project to exhibit selective extraction of sodium. Simple aqueous phases, such as sodium nitrate and sodium hydroxide mixtures, as well as complex waste simulants were successfully treated. 
Quantitative recovery of sodium hydroxide from the loaded solvents by stripping with water was demonstrated, and it was shown that sufficiently lipophilic extractants could be cycled several times without loss of performance. Selectivity for hydroxide over nitrate transfer exceeds 20:1. Efforts in the past year have addressed several issues pertaining to solvent capacity. It has been found that good loading of the solvent exceeding $1 \mathrm{M}$ sodium can be achieved, but high solvent viscosity or even gelation occurs at $25{ }^{\circ} \mathrm{C}$. This may be overcome by performing extraction and stripping at $60{ }^{\circ} \mathrm{C}$, and isotherms have been obtained for several candidate extractants. It was shown that greater than $90 \%$ of the free hydroxide in a simple tank-waste simulant (alkaline nitrate solution containing aluminate) may be recovered. At least two extractants appear to be viable for process use in terms of efficacy and cost. Caustic recycle applications include recycle of sodium hydroxide at several DOE sites as well as in certain industrial processes. A patent application has been filed and is near issuance as a first step toward attracting users and ultimately transferring the technology. A spin-off proposal to the EM-50 Efficient Separations and Processing Crosscutting Program was funded in FY01 and FY02 to adapt this technology to a Hanford application.

As a first demonstration of "synergized pseudo hydroxide extraction," exciting synergistic effects in sodium hydroxide separation have been discovered by combining fluorinated alcohols with macrocyclic extractants. Prof. Alan Marchand and his group at the University of North Texas are carrying out synthesis of novel crown ethers and podands. The UNT group has devised workable synthetic methodology to produce a series of novel cage-annulated oxa- and aza-crown ethers (a) that possess varying cavity sizes and shapes and (b) that differ in the number and nature of the donor atoms contained in the macrocyclic system. A crystal structure of one of the aza macrocycles, as an $\mathrm{HCl}$ salt, has been determined, providing valuable information on the macrocycle's preferred conformation. By appropriate variation of macrocycle structure, the strength and selectivity of extraction of alkali metal cations may be controlled, as shown in standard picrate extraction surveys. Although the macrocycles used alone tend to favor the extraction of sodium salts of large anions, sodium extraction from hydroxide solutions jumps sharply when the macrocycles are added to active fluorinated alcohols. Large synergistic effects have been recorded, sufficient to make hydroxide separation competitive with the more abundant nitrate. These successful prototype systems have provided valuable information that is guiding continuing efforts to design more effective host species. One such direction entails ditopic pseudo hydroxide extractants, and a first example was successfully synthesized and delivered to ORNL.

\section{Planned Activities}

During the final two months of the project, study of the extraction behavior of the ditopic receptor mentioned above will be initiated. The primary goal will be to demonstrate that pseudo hydroxide extraction is operating and to initiate evaluation of whether the ditopic receptor offers advantages over the simpler synergized pseudo hydroxide extraction.

In the renewal 3-year period, a collaborative project involving Oak Ridge National Laboratory, Pacific Northwest National Laboratory (G. J. Lumetta), and the University of North Texas (Prof. A. P. Marchand) will be undertaken to explore new approaches to the separation of sodium hydroxide, sodium nitrate, and other sodium salts from high-level alkaline tank waste. The principal potential benefit of this research will be a major reduction in the volume of the high-activity waste stream, obviating the building of expensive new waste tanks and reducing the costs of vitrification. Principles of ion recognition will be researched toward discovery of liquid- 
liquid extraction systems that selectively separate sodium hydroxide and nitrate from waste-like matrices. Successful approaches to sodium hydroxide separation that were discovered in the prior three years will be enhanced by further efforts to understand the underlying properties of the controlling equilibria. This work will employ the novel concept of pseudo hydroxide extraction by fluorinated alcohols and phenols that function by cation exchange at elevated $\mathrm{pH}$ values. Crown ethers designed for sodium binding will be examined as possible synergists, and new ionizable lariat ethers will be synthesized as a new class of pseudo hydroxide extractants (UNT). A new thrust will be initiated to specifically target sodium nitrate. Applicable principles to be understood include solvation effects that promote efficient sodium nitrate extraction and appropriate crown ether design for efficient sodium binding and rejection of cesium. A proposed approach to the combined removal of sodium salts will be examined. Studies with real tank waste at PNNL will provide feedback toward solvent designs that have desirable properties.

\section{Information Access}

A complete list of publications, patent application, and presentations for this project is also

available as optional additional information associated with this annual report. See also www home page of the ORNL Chemical Separations Group: http://www.ornl.gov/csg. 


\title{
PUBLICATION LIST
}

\section{Ion Recognition Approach to Volume Reduction of Alkaline Tank Waste by Separation and Recycle of Sodium Hydroxide and Sodium Nitrate}

\section{ENVIRONMENTAL MANAGEMENT SCIENCE PROGRAM PROJECT NO. 65339}

Sept., 1998 to Aug., 2001

\section{REPRINTS AVAILABLE ON REQUEST.}

Chemical Separations Group, Chemical and Analytical Sciences Division, Oak Ridge National Laboratory, P. O. Box 2008, Bldg. 4500S, MS-6119, Oak Ridge, TN 37831-6119, U.S.A. Ph.: 865-574-6718. FAX: 865-574-4939. Email: moyerba@ornl.gov. WWW home page: http://www.ornl.gov/csg.

Prof. Alan P. Marchand, Department of Chemistry, University of North Texas, NT Station, P.O. Box 305070, Denton, TX 76203-5070. Ph.: 940-565-3823. FAX: 940-565-4318. E-mail: marchand@unt.edu

\begin{abstract}
This research was sponsored by the Environmental Management Science Program of the Offices of Science and Environmental Management, U. S. Department of Energy, under a) contract number DE-AC05-00OR22725 with Oak Ridge National Laboratory, managed and operated by UT-Battelle, LLC, and b) Grant number DE-FG0798ER14936 with the University of North Texas.
\end{abstract}

\section{Patent Status}

Application to U.S. Patent Office: B. A. Moyer, C. K. Chambliss, P. V. Bonnesen, and T. J. Keever, "Solvent and Process for Recovery of Hydroxide from Aqueous Mixtures," Ser. No. 09/404,104, Sept. 23, 1999. ORNL Disclosure No. 0738, July 20, 1999.

\section{$\underline{\text { Publications }}$}

S. M. Blair, J. S. Brodbelt, A. P. Marchand, K. A. Kumar, and H.-S. Chong, "Evaluation of Binding Selectivities of Caged Crown Ligands Towards Heavy Metals by Electrospray Ionization/Quadrupole Ion Trap Mass Spectrometry," Anal. Chem., 72, 2433-2445 (2000).

S. M. Blair, J. S. Brodbelt, A. P. Marchand, H.-S. Chong, and S. Alihodzic, "Evaluation of Alkali Metal Binding Selectivities of Caged Aza-Crown Ether Ligands by Electrospray Ionization Quadrupole Ion Trap Mass Spectrometry," J. Am. Soc. Mass Spectrom., 11, 884-891 (2000).

J. C. Bryan, K. Mlinaric-Majerski, G. Kragol, and A. P. Marchand, "Crystal Structure of 1,3-Hydroxymethyl-2oxaadamantane, $\mathrm{G}_{1} \mathrm{H}_{18} \mathrm{O}_{3}$," Z. Kristallogr., 216, 277-279 (2001). Joint sponsorship with the Robert A. Welch Foundation, the Texas Advanced Technology Program, and the Ministry of Science and Technology of the Republic of Croatia.

J. C. Bryan, T. G. Levitskaia, C. Giacovazzo, G. Cascarano, A. P. Marchand, Z. Huang, V. S. Kumar, and T. D. Power, "Synthesis, Alkali Metal Picrate Extraction Properties, and X-ray Crystal Structure of a Novel, Cage-Annulated 18Crown-6 Host," Struct. Chem. 12, 275-282 (2001) (Invited).

J. C. Bryan, A. P. Marchand, and A. Hazlewood, “N,N'-Diacetyl-1,13-diaza-24-crown-8,” Acta Crystallogr. E, 57, o1315 (2001).

C. K. Chambliss, T. J. Haverlock, P. V. Bonnesen, N. L. Engle, and B. A. Moyer, "Selective Separation of Hydroxide from Alkaline Media by Liquid-Liquid Extraction with Weak Hydroxy Acids," Environ. Sci. Technol. (Submitted). 
T. J. Haverlock, P. V. Bonnesen, G. M. Brown, C. K. Chambliss, T. G. Levitskaia, and B. A. Moyer, "Separation of $\mathrm{NaOH}$ from Salts by Weak Hydroxy Acids," Proc. International Solvent Extraction Conference ISEC '02, Cape Town, South Africa, March 18-21, 2002 (Submitted).

T. Hayashita, T. Higuchi, H. Sawano, A. P. Marchand, K. A. Kumar, S. G. Bott, K. Mlinaric-Majerski, T. Sumanovac, N. S. Elkarim, H.-S. Hwang, G. Talanova, and R. A. Bartsch, "Molecular Design of Lipophilic Disalicylic Acid Compounds with Varying Spacers for Selective Lead(II) Extraction," Talanta, 52, 385-396 (2000).

T. G. Levitskaia, B. A. Moyer, P. V. Bonnesen, A. P. Marchand, K. Krishnudu, Z. Chen, Z. Huang, H. G. Kruger, and A. S. McKim "Novel Approach to Sodium Hydroxide Separation: Synergistic Pseudo Hydroxide Ion Extraction by a Fluorinated Alcohol and Cage-Functionalized Crown Ethers," J. Am. Chem. Soc. (Submitted).

A. T. Macias, K. A. Kumar, A. P. Marchand, and J. D. Evanseck, "Synthesis and Inclusion Complexation Studies of a Novel and Selective Molecular Receptor for 1,4-Disubstituted Benzenes and 4,4'-Disubstituted Biphenyls," J. Org. Chem., 65, 2083-2089 (2000).

A. P. Marchand, Z. Huang, Z. Chen, H. K. Hariprakasha, I. N. N. Namboothiri, J. S. Brodbelt, and M. L. Reyzer, "Synthesis, Alkali Metal Picrate Extraction, and Alkali Metal Cation Binding Selectivities of Some New CageAnnulated Polyoxamacrocyclic Crown Ethers," J. Heterocyclic Chem., In press (2001).

A. P. Marchand, M. Takhi, V. S. Kumar, K. Krishnudu, and B. Ganguly, "Synthesis of Novel Chiral, Cage-annulated Macrocycles," ARKIVOC, July, 2001; URL: http://www.arkat.org/arkat/journal/Issue 10/ms3/ms3.htm.

A. P. Marchand, K. A. Kumar, A. S. McKim, S. Alihodzic, H.-S. Chong, K. Krishnudu, and M. Takhi, "Novel CageAnnulated Crown Ethers, Cryptands, and Molecular Boxes: A New Class of Ionophores for Selective Ion Complexation," Kem. Ind., 50, 129-138 (2001).

A. P. Marchand, H.-S. Chong, M. Takhi, W. H. Watson, and S. G. Bodige, "Synthesis and Extraction Studies of an Unusual Cage-Funtionalized Cryptand," Heterocycles, 54, 151-158 (2001).

A. P. Marchand, H.-S. Chong, M. Takhi, and T. D. Power, "Synthesis and Alkali Metal Picrate Extraction Studies of ptert-Butylcalix[4]arene Crown Ethers Bridged at the Lower Rim with Pyridyl Units," Tetrahedron, 56, 3121-3126 (2000).

A. P. Marchand, H.-S. Chong, S. Alihodzic, W. H. Watson, and S. G. Bodige, "Synthesis and Alkali Metal Picrate Extraction Capabilities of Novel, Cage-functionalized, Pyridine-containing Crown Ethers and Cryptands," Tetrahedron, 55, 9687-9786 (1999).

A. P. Marchand and H.-S. Chong, "Synthesis and Alkali Metal Picrate Extraction Capabilities of Novel, CageFuntionalized Diaza(17-crown-5) Ethers," Tetrahedron, 55, 9697-9706 (1999).

B. A. Moyer, P. V. Bonnesen, C. K. Chambliss, T. J. Haverlock, A. P. Marchand, H-S. Chong, A. S. McKim, K. Krishnudu, K. S. Ravikumar, V. S. Kumar, and M. Takhi, "Use of Cage-Functionalized Macrocycles and Fluorinated Alcohols in the Liquid-Liquid Extraction of $\mathrm{NaOH}$ and other Sodium Salts: Strategies Toward Waste-Volume Reduction," in Nuclear Site Remediation: First Accomplishments of the Environmental Science Program, ACS Symposium Series, Vol. 778, P. G. Eller and W. R. Heineman, Eds., American Chemical Society, Washington, DC, 2001; pp. 114-132 (Invited).

A. A. Pinkerton, M. J. Hardie, A. P. Marchand, and K. A. Kumar, "Synthesis of an Unusual, Cage-Functionalized Molecular Cleft," J. Chem. Crystallogr., In press (2001).

M. L. Reyzer, J. S. Brodbelt, A. P. Marchand, Z. Chen, Z. Huang, and I. N. N. Namboothiri, "Determination of Alkali Metal Binding Selectivities of Caged Crown Ligands by Electrospray Ionization Quadrupole Ion Trap Mass Spectrometry," Int. J. Mass Spectrom. 204, 133-142 (2001).

W. H. Watson, S. G. Bodige, A. P. Marchand, and H.-S. Chong, "A One-Pot Synthesis Of Cage-Functionalized, KetalContaining Crown Ethers," Struct. Chem. 11, 257-260 (2000).

\section{$\underline{\text { Miscellaneous Reports and Summaries }}$}


A. P. Marchand, "Ion Recognition Approach to Volume Reduction of Alkaline Tank Waste by Separation and Recycle of Sodium Hydroxide and Sodium Nitrate," Environmental Management Science Program Fiscal Year 1998 Awards Annual Progress Report, June 3, 1999; Letter-form report sent to Ms. Kara L. Twitchell, Procurement Services Division, U. S. Department of Energy, Idaho Operations Office.

B. A. Moyer, P. V. Bonnesen, G. M. Brown, T. J. Haverlock, and T. G. Levitskaia, "Solvent Extraction Approach to Sodium Hydroxide Recycle from Alkaline Tank Waste. Results from EM Science Program Project No. 65339," Technology description and progress report provided to CH2MHILL, Nov., 2000.

B. A. Moyer, P. V. Bonnesen, G. M. Brown, J. C. Bryan, C. K. Chambliss, T. J. Haverlock, T. G. Levitskaia, A. P. Marchand, Z. Chen, H.-S. Chong, H. K. Hariprakasha, Z. Huang, K. Krishnudu, H. G. Kruger, V. S. Kumar, A. S. McKim, K. S. Ravikumar, and M. Takhi, "Ion Recognition Approach to Volume Reduction of Alkaline Tank Waste by Separation and Recycle of Sodium Hydroxide and Sodium Nitrate," FY 2001 Ann. Rep., Oak Ridge National Laboratory, Oak Ridge, TN, Jun., 2000; posted on the WWW site of the USDOE Environmental Management Science Program.

B. A. Moyer, P. V. Bonnesen, G. M. Brown, J. C. Bryan, C. K. Chambliss, T. J. Haverlock, T. G. Levitskaia, A. P. Marchand, H.-S. Chong, H. K. Hariprakasha, K. Krishnudu, V. S. Kumar, A. S. McKim, K. S. Ravikumar, M. Takhi, "Ion Recognition Approach to Volume Reduction of Alkaline Tank Waste by Separation and Recycle of Sodium Hydroxide and Sodium Nitrate," FY 2000 Ann. Rep., Oak Ridge National Laboratory, Oak Ridge, TN, Jun., 2000; posted on the WWW site of the USDOE Environmental Management Science Program.

B. A. Moyer, P. V. Bonnesen, J. C. Bryan, C. K. Chambliss, T. J. Haverlock, T. G. Levitskaia, A. P. Marchand, H.-S. Chong, A. S. McKim, K. Krishnudu, K. S. Ravikumar, V. S. Kumar, M. Takhi, and H. K. Hariprakasha, "Ion Recognition Approach to Volume Reduction of Alkaline Tank Waste by Separation and Recycle of Sodium Hydroxide and Sodium Nitrate," Environmental Management Science Program Fiscal Year 1998 Awards FY 2000 Project Summary, Apr. 25, 2000; available on World Wide Web site of the USDOE Office of Environmental Management.

B. A. Moyer, C. K. Chambliss, T. J. Haverlock, P. V. Bonnesen, J. C. Bryan, and A. P. Marchand, "Ion Recognition Approach to Volume Reduction of Alkaline Tank Waste by Separation and Recycle of Sodium Hydroxide and Sodium Nitrate," Environmental Management Science Program Fiscal Year 1998 Awards Annual Progress Report, Jun. 15, 1999; available on World Wide Web site of the USDOE Office of Environmental Management.

\section{Presentations}

B. A. Moyer, P. V. Bonnesen, C. K. Chambliss, T. J. Haverlock, and T. G. Levitskaia, "Separation of NaOH from Salts by Weak Hydroxy Acids," Internat. Solvent Extr. Conf. ISEC '02, Cape Town, South Africa, Mar. 18-21, 2002, (CONTRIBUTED - ORAL PRESENTATION).

T. G. Levitskaia, B. A. Moyer, P. V. Bonnesen, A. P. Marchand, K. Krishnudu, Z. Chen, Z. Huang, H. G. Kruger, and A. S. McKim, "Novel Approach to $\mathrm{NaOH}$ Separation: Synergistic Pseudo-Hydroxide Extraction by a Fluorinated Alcohol and Cage-Functionalized Crown Ethers," ACS National Meeting, Chicago, IL, Aug. 26-30, 2001 (CONTRIBUTED - ORAL PRESENTATION).

A. P. Marchand, T. D. Power, B. A. Moyer, T. G. Levitskaia, P. V. Bonnesen, and J. C. Bryan, "Ion-Pair Extraction by Using Cage-Functionalized Hosts: Strategy for Selective Extraction of NaOH from Wastes," ACS National Meeting, Chicago, IL, Aug. 26-30, 2001 (CONTRIBUTED - ORAL PRESENTATION).

B. A. Moyer, P. V. Bonnesen,, G. M. Brown, J. C. Bryan, L. H. Delmau, T. J. Haverlock, T. G. Levitskaia, and F. J. Sloop, "Liquid-Liquid Extraction Approaches o the Treatment of Alkaline High-Level Waste," ACS National Meeting, Chicago, IL, Aug. 26-30, 2001 (INVITED - KEYNOTE LECTURE).

A. P. Marchand, "Evaluation of Binding Selectivities of Cage-Annulated Crown Ligands Toward Alkali Metal and Heavy Metal Cations by Electrospray Ionization/Quadrupole Ion Trap Mass Spectrometry," Rudjer Boskovic Institute, Zagreb, Croatia, June 20, 2001 (Colloquium -INVITED). 
A. P. Marchand, "From Cage Compounds to Molecular Clefts. Novel Cage-Annulated Crown Ethers, Cryptands, and Molecular Boxes: A New Class of Ionophores for Selective Ion Complexation," Department of Chemistry, Rutgers University, Newark, NJ, April 27, 2001 (Departmental seminar speaker - INVITED).

A. P. Marchand, "From Cage Compounds to Molecular Clefts. Novel Cage-Annulated Crown Ethers, Cryptands, and Molecular Boxes: A New Class of Ionophores for Selective Ion Complexation," Department of Chemistry, Rutgers University, New Brunswick, NJ, April 26, 2001 (Departmental seminar speaker - INVITED).

P. V. Bonnesen, L. H. Delmau, N. L. Engle, T. J. Haverlock, T. G. Levitskaia, B. A. Moyer, “Application of Fluorinated Alcohols in Metal Ion Solvent Extraction Processes for Nuclear Waste Disposal and Environmental Remediation," $221^{\text {st }}$ Meeting of the ACS, San Diego, CA, A pr. 1-5, 2001.

A. P. Marchand, Z. Huang, Z. Chen, H. K. Hariprakasha, I. N. N. Namboothiri, J. S. Brodbelt, and M. L. Reyzer, "Synthesis, Alkali Metal Picrate Extraction, and Alkali Metal Cation Binding Selectivities of Some New CageAnnulated Polyoxamacrocyclic Crown Ethers," 2nd Florida Heterocyclic Conference, University of Florida, Gainesville, FL, March 7-9, 2001 (CONTRIBUTED - poster presentation).

B. A. Moyer, P. V. Bonnesen, C. K. Chambliss, G. M. Brown, and T. J. Haverlock, "Liquid-Liquid Separation of NaOH Using Fluorinated Alcohols and Phenols," Pacifichem 2000, Honolulu, HI, Dec. 14-19, 2000 (INVITED - ORAL PRESENTATION in the symposium "Separations Science: Trends for the New Century").

Alan P. Marchand, "Synthesis and Chemistry of Unnatural Products: From Cage Compounds to Molecular Clefts. Novel Cage-Annulated Crown Ethers, Cryptands, and Molecular Boxes: A New Class of Ionophores for Selective Ion Complexation," Department of Chemistry, University of Texas at San Antonio (UTSA), San Antonio, TX, November 3, 2000 (INVITED - Departmental seminar speaker).

A. P. Marchand, "Novel Cage-Annulated Crown Ethers, Cryptands, and Molecular Boxes: A New Class of Ionophores for Selective Ion Complexation," Department of Chemistry, New Mexico Tech, Soccorro, NM, October 13, 2000 (INVITED - Departmental seminar speaker).

Alan P. Marchand, "Crown Ethers, Cryptands, and Molecular Boxes Derived from Function-alized Pentacycloundecanediones. A New Class of Ionophores for Selective Ion Complexation," Chemical Separations Group, Chemical \& Analytical Sciences Division, Oak Ridge National Laboratory, Oak Ridge, TN, October 2 , 2000 (INVITED).

A. P. Marchand, K. A. Kumar, A. S. McKim, S. Alihodzic, H.-S. Chong, K. Krishnudu, M. Takhi, K. Mlinaric-Majerski, G. Kragol, and T. Sumanovac, "Crown Ethers, Cryptands, and Molecular Boxes Derived from Functionalized Pentacyclo[5.4.0.0<2,6>.0<3,10>.0<5,9>] undecane-4,11-diones. A New Class of Ionophores for Selective Ion Complexation," 80th Annual Meeting of the Polish Chemical Society, September 11-15, 2000, Session No. 1, Paper No. W -8. (INVITED - PLENARY LECTURE)

Alan P. Marchand, Mohamed Takhi, V. Satish Kumar, Kasireddy Krishnudu, Bishwajit Ganguly, Jennifer S. Brodbelt, and Michelle Reyzer, "Novel Chiral, Cage-Annulated Macrocycles," 220th National Meeting of the American Chemical Society, Washington, DC, August 20-25, 2000, Paper No. ORGN-478 (CONTRIBUTED - oral presentation).

A. P. Marchand, K. A. Kumar, A. S. McKim, S. Alihodzic, H.-S. Chong, K. Krishnudu, M. Takhi, K. Mlinaric-Majerski, G. Kragol, and T. Sumanovac, "Novel Cage-Annulated Crown Ethers, Cryptands, and Molecular Boxes: A New Class of Ionophores for Selective Ion Complexation," Central European Chemical Meeting (CECM-1), Varazdin, Croatia, June 14-17, 2000 (INVITED - PLENARY LECTURE).

Alan P. Marchand, "Synthesis and Chemistry of Unnatural Products: From Cage Compounds to Molecular Clefts. Novel Cage-Annulated Crown Ethers, Cryptands, and Molecular Boxes: A New Class of Ionophores for Selective Ion Complexation," Department of Chemistry, Texas Tech University, Lubbock, TX, May 3, 2000 (INVITED Departmental seminar speaker).

A. P. Marchand, A. S. McKim, H.-S. Chong, K. Krishnudu, M. Takhi, V. S. Kumar, Z. Chen, and Z. Huang, "Cagefunctionalized, Nitrogen-containing Crown Ethers and Podands; Potential New Host Systems for Extraction of NaOH from Wastes," EMSP Workshop, sponsored by the U. S. Department of Energy, Atlanta, GA, April 25-27, 2000 (POSTER - INVITED). 
B. A. Moyer, P. V. Bonnesen, C. K. Chambliss, T. J. Haverlock, A. P. Marchand, H-S Chong, A. S. McKim, K. Krishnudu, K. S. Ravikumar, V. S. Kumar, M. Takhi, and H. K. Hariprakasha, "Strategies Toward Reduction of HighLevel Waste Volume: Use of Fluorinated Alcohols and Cage-Functionalized Macrocycles in the Extraction of NaOH," Second Environmental Management Science Program National Workshop, Atlanta, GA, April 25-27, 2000 (INVITED ORAL PRESENTATION AND POSTER).

Z. Chen and A. P. Marchand, "Synthesis and Alkali Metal Picrate Extraction Capabilities of Cage-annulated Crownand Azacrown Ethers. Part I.," 33rd Annual ACS-DFW Meeting-in-Miniature, University of North Texas, Denton, TX, April 15, 2000, Graduate Section; Paper No. G-03 (CONTRIBUTED - ORAL PRESENTATION).

A. Hazlewood and A. P. Marchand, "Synthesis and Properties of Novel, Cage-functionalized Macrocyclic Crown Ethers and Cryptands. Part I.," 33rd Annual ACS-DFW Meeting-in-Miniature, University of North Texas, Denton, TX, April 15, 2000, Graduate Section; Paper No. G-01 (CONTRIBUTED - ORAL PRESENTATION).

Z. Huang and A. P. Marchand, "Synthesis and Alkali Metal Picrate Extraction Capabilities of Cage-annulated Crownand Azacrown Ethers. Part I.," 33rd Annual ACS-DFW Meeting-in-Miniature, University of North Texas, Denton, TX, April 15, 2000, Graduate Section; Paper No. G-02 (CONTRIBUTED - ORAL PRESENTATION).

M. P. Unni and A. P. Marchand, "Synthesis and Properties of Novel, Cage-functionalized Macrocyclic Crown Ethers and Cryptands. Part II.," 33rd Annual ACS-DFW Meeting-in-Miniature, University of North Texas, Denton, TX, April 15, 2000, Undergraduate Section, Paper No. U-03 (CONTRIBUTED - ORAL PRESENTATION).

A. T. Macias, K. A. Kumar, A. P. Marchand, and J. D. Evanseck, "Synthesis and Inclusion Complexation Studies of a Novel Molecular Receptor for 1,4-Disubstituted Benzenes and 4,4'-Disubstituted Biphenyls," 219 th National Meeting of the American Chemical Society, San Francisco, CA, March 26-30, 2000, Paper No. COMP-103 (CONTRIBUTED POSTER).

A. P. Marchand, "Novel Cage-Annulated Crown Ethers, Cryptands, and Molecular Boxes: A New Class of Ionophores for Selective Ion Complexation," Department of Chemistry, Southern Methodist University, Dallas, TX, February 28, 2000 (INVITED - DEPARTMENTAL SEMINAR).

B. A. Moyer, P.V. Bonnesen, C. K. Chambliss, T. J. Haverlock, A. P. Marchand, H.-S. Chong, A. S. McKim, K. Krishnudu, K. S. Ravikumar, V. S. Kumar, and M. Takhi, "Ion-Pair Recognition: Targeting NaOH," Dept. of Chemistry, Univ. of North TX, Jan. 19, 2000 (DEPARTMENTAL SEMINAR).

S. M. Blair, J. S. Brodbelt, A. P. Marchand, H.-S. Chong, K. A. Kumar, and S. Alihodzic, "Evaluation of Binding Selectivities of Caged Crown Ligands Toward Metal Cations By Using Electrospray Ionization Quadrupole Ion Trap Mass Spectro-metry," 218th National Meeting of the American Chemical Society, New Orleans, LA, August 22-26, 1999, Paper No. NUCL-080 (INVITED - POSTER PRESENTATION in the Symposium on "First Accomplishments of the Environmental Management Science Program").

S. M. Blair, J. S. Brodbelt, A. P. Marchand, H.-S. Chong, K. A. Kumar, and S. Alihodzic, "Evaluation of Binding Selectivities of Caged Crown Ligands Toward Metal Cations By Using Electrospray Ionization Quadrupole Ion Trap Mass Spectrometry," 218th National Meeting of the American Chemical Society, New Orleans, LA, August 22-26, 1999, (INVITED - POSTER PRESENTATION in the Sci-Mix that followed the Symposium on "First Accomplishments of the Environmental Management Science Program").

A. P. Marchand, H.-S. Chong, S. Alihodzic, W. H. Watson, and S. G. Bodige, "Synthesis and Alkali Metal Picrate Extraction Capabilities of Novel, Cage-functionalized, Pyridine-containing Crown Ethers and Cryptands," 218th National Meeting of the American Chemical Society, New Orleans, LA, August 22-26, 1999, Paper No. NUCL-081 (INVITED - POSTER PRESENTATION in the Symposium on "First Accomplishments of the Environmental Management Science Program").

A. P. Marchand, H.-S. Chong, A. S. McKim, K. Krishnudu, K. S. Ravikumar, V. S. Kumar, and M. Takhi, B. A. Moyer, C. K. Chambliss, P. V. Bonnesen, and J. C. Bryan, "Cage-functionalized, Nitrogen-containing Macrocycles and Podands; Potential New Host Systems for Extraction of NaOH from Wastes," 218th National Meeting of the American Chemical Society, New Orleans, LA, August 22-26, 1999, Paper No. NUCL-108 (INVITED - ORAL PRESENTATION in the Symposium on "First Accomplishments of the Environmental Management Science Program"). 
A. P. Marchand, "Crown Ethers, Cryptands, and Molecular Boxes Derived from Functionalized Pentacyclo[5.4.0.02,6.03,10.05,9]undecane-4,11-diones. A New Class of Ionophores for Selective Ion Complexation," PLIVA Pharmaceutical Company, Zagreb, Croatia, June 18, 1999, (INVITED - ORAL PRESENTATION).

S. M. Blair, J. S. Brodbelt, A. P. Marchand, H.-S. Chong, K. A. Kumar, and S. Alihodzic, "Evaluation of Binding Selectivities of Caged Crown Ligands Toward Metal Cations By Using Electrospray Ionization Quadrupole Ion Trap Mass Spectrometry," Conference: "An Aging Planet, An Expanding Population and A Sustainable Future: Changing Attidues and Values," sponsored by the Center for Public Service, Institute for Applied Sciences and by the Environmental Alliance for Senior Involvement, University of North Texas, May 28, 1999 (INVITED - POSTER PRESENTATION).

A. P. Marchand, K. A. Kumar, A. S. McKim, S. Alihodzic, H.-S. Chong, K. Mlinaric-Majerski, G. Kragol, and T. Sumanovac, "Novel Cage-Annulated Crown Ethers, Cryptands, and Molecular Boxes: A New Class of Ionophores for Selective Ion Complexation," 8th Lodz-Lyon Seminar Series, Mazury Poland, May 25-30, 1999, (INVITED - PLENARY LECTURE).

A. P. Marchand and H.-S. Chong, "Syntheses and Alkali Metal Picrate Extraction Capabilities of Novel, CageFunctionalized, Pyridine-Containing Crown Ethers and Cryptands," 32nd Annual ACS Meeting-in-Miniature, University of Texas at Dallas, Richardson, TX, April 16, 1999, (CONTRIBUTED - ORAL PRESENTATION).

A. P. Marchand and H.-S. Chong, "Syntheses and Alkali Metal Picrate Extraction Capabilities of Novel, CageFunctionalized, Pyridine-Containing Crown Ethers and Cryptands," 2nd Annual Graduate Research/ Performance Fair, University of North Texas, Denton, TX, April 13-14, 1999, (CONTRIBUTED - POSTER PRESENTATION).

R. A. Sachleben, B. A. Moyer, J. C. Bryan, and A. P. Marchand, "Ion Recognition Approach to Volume Reduction of Alkaline Tank Waste by Separation and Recycle of Sodium Hydroxide and Sodium Nitrate," EMSP Tanks Focus Area (TFA) Workshop, Richland, WA, Nov. 17-18, 1998. (INVITED ORAL PRESENTATION). 